\title{
Study of the impact of consanguinity on abortion and mortality in the population of Beni Abbes (southwestern Algeria)
}

\author{
Said Bachir ${ }^{1,2^{*}}$ and Ammaria Aouar ${ }^{1}$
}

\begin{abstract}
Background: Despite the numerous studies confirming the involvement of consanguinity in health problems, some populations around the world continue to practice this marital behavior. Algeria, like many Arab-Muslim countries, has very high consanguinity rates that require studies to measure the effects on public health. This study aims to estimate the frequency of consanguinity and to analyze its effects on two health indicators, namely abortion, neonatal, and postnatal mortality, and it focused on the population of Beni Abbes in southwestern Algeria previously known to be a genetic isolate.

Results: The results of the study revealed a high consanguinity rate of $55.06 \%$ with a clear preference of first cousin marriages. A highly significant correlation was highlighted between inbreeding and the incidence of abortion as well as post and neonatal mortality.

Conclusion: These results are an encouraging indicator for further future genetic studies on this population, especially since this locality is likely to remain a genetic isolate. In order to reduce the adverse health effects of consanguinity, it is essential to establish genetic counseling services in health facilities and to promote the dissemination of information on risks arising from consanguineous marriages through health education for populations.
\end{abstract}

Keywords: Abortion, Beni Abbes (Algeria), Consanguineous marriage, Mortality, Population

\section{Background}

Marriage is the basic institution that decides most gene redistributions among individuals over generations, so we can closely monitor the fate of the population's genetic heritage [1].

Inbreeding is a special case of matrimonial relationships between spouses, defined as the phenomenon that results from the union between blood-related individuals, having at least one common ancestor.

Geneticists classify consanguineous marriage according to the coefficient of consanguinity, defined by the probability that a consanguineous individual has at a given locus, two identical alleles [2].

\footnotetext{
* Correspondence: saidgenet64@gmail.com

1 Laboratory for the Valorisation of Human Action for the Protection of the Environment and Application in Public Health (Environment and Health team), Faculty of Science, Abou Bekr Belkaid University of Tlemcen, Tlemcen, Algeria

2Tahri Mohamed University, BP No. 147, 08000 Béchar, Algeria
}

Inbreeding marriages have been practiced since the existence of man. The frequency of consanguineous unions depends on the size of the population, its degree of isolation, and it is influenced by socio-economic and cultural practices [3]. Currently, about $20 \%$ of the world's populations live in consanguineous communities [4].

In Algeria, consanguineous marriages have been celebrated since ancient times in all regions and all social strata; they appear as a current, preferential, and normative social practice where the marriage between first cousins is the most frequent type [5].

One of the major consequences of such practices is the considerable reduction of inter- and intra-population genetic variability. As a result of inbreeding, the degree of homozygosity increases both at the level of individuals and at the level of populations, a fact that will have an impact on an increase in the rate of abnormalities by fixation of deleterious genes [6].

The consequences of consanguineous marriage, particularly on fertility, mortality, and morbidity, have since a 
long time been of a great interest to doctors and geneticists. That has led to an abundance of publications since the end of the 20th century [4, 7-13].

Similarly, studies conducted to investigate the effects of consanguinity on Algerian populations' public health [14-17] have also emphasized the importance of consanguinity, which remains a social phenomenon and a privileged marriage practice justified by financial and emotional security.

The present study is a continuation of studies conducted in Algeria where consanguineous marriages are a common practice. It is devoted to the population of Beni Abbes in southwestern Algeria (Fig. 1)

We aim to describe at best the perception of consanguineous marriages, to determine the frequency of consanguinity and to estimate its effects on health through two indicators (abortion, neonatal, and postnatal mortality).

\section{Methods}

For the realization of our investigation, we conducted for a period of about 2 years (09 spaced stays) a prospective survey in a hospital (Beni Abbes PHEP) which involved 267 people living in couples that originated from the region for at least three generations.

The interviewees were randomly selected (we did not know if they had a consanguineous relationship or not) among the women hospitalized in the department of maternity and failing that, we interviewed their husband. They were invited to fill out a questionnaire preestablished by our environment and health team of the laboratory for the promotion of human action for the protection of the environment and its application in public health at Abu Baker Belkaid University of Tlemcen, from which a number of health, socio-demographic, and cultural data were collected.

Everyone included in this study is informed and has given us written consent in accordance with Executive Decree No. 92-276 of 6 July 1992 on the Algerian Code of Medical Ethics [18].

\section{Data processing}

To analyze the fertility of couples and the mortality of their offspring in our population, we calculated abortion and mortality rates. In addition, we estimated for these

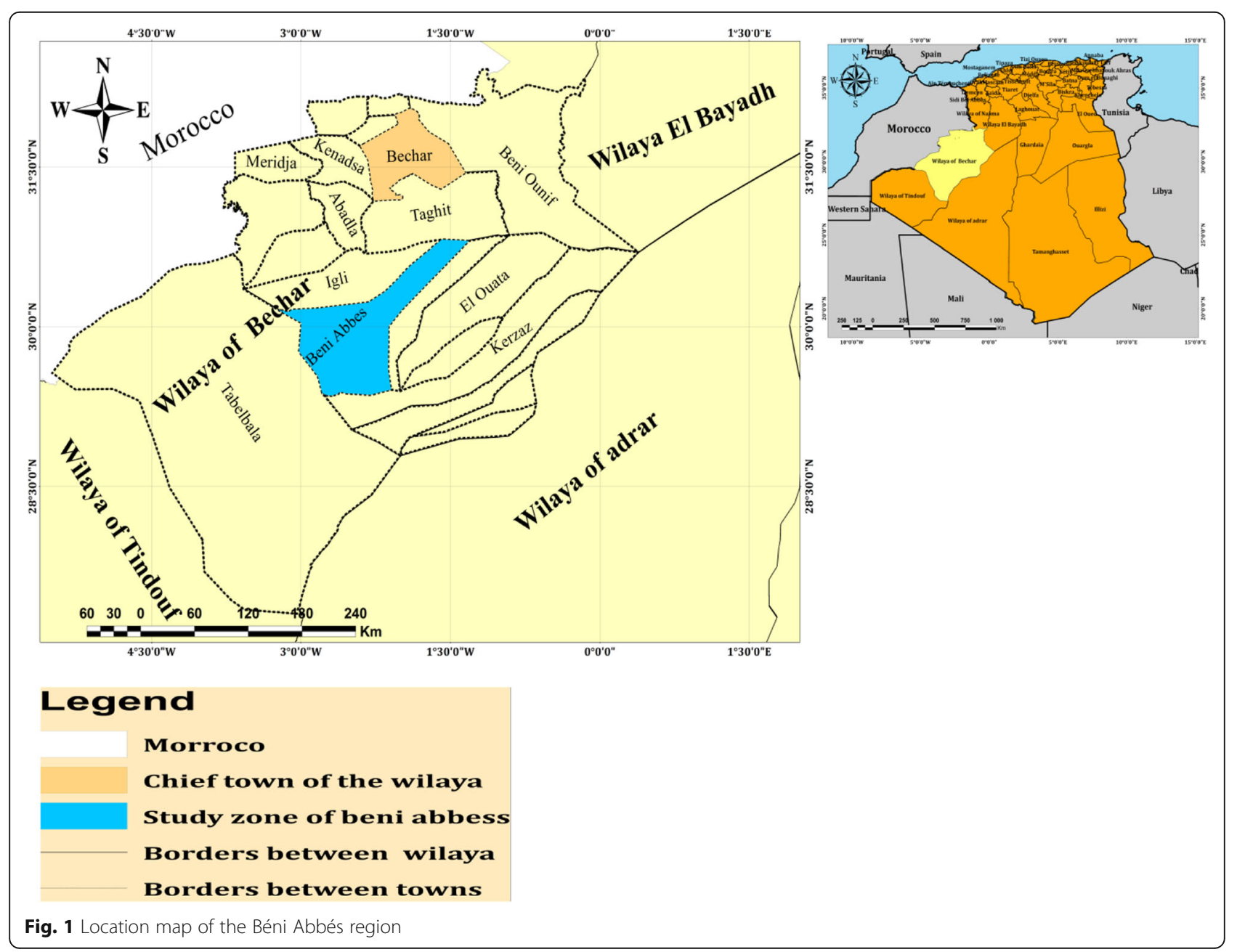


parameters the relative risk and attributable risk (Epidemiology: Principles and Quantitative Methods) [19].

\section{Relative risk}

Relative risk (RR) is determined by the ratio of the probability of death among children from consanguineous marriages (Rc) and the probability of death among children from non-consanguineous marriages (Rnc): $R R=R c / R n c$.

A relative risk greater than 1 means that the risk of mortality among children from consanguineous marriages is higher compared to that of children from nonconsanguineous marriages. If the $R R$ is 1 , the offspring of consanguineous marriages is not considered to be more risky than that of non-consanguineous marriages. However, if the RR is included between 0 and 1, the risk of mortality among children from consanguineous marriages is lower than that of children from non-consanguineous marriages.

\section{Attributable risk}

Attributable risk (AR) is the portion of the risk that can be directly related to the factor under study. In our case, this is indeed the "consanguinity" factor. Proportional attributable risk of the population (RAPP) is a risk that takes into account the frequency of inbreeding ( $\mathrm{Pc}$ ) in the population and is calculated according to the formula: $\mathrm{RApp}=\mathrm{Pc}(\mathrm{RR}-1) / 1+\mathrm{Pc}(\mathrm{RR}-1)$.

A high mortality rate associated with consanguinity can be expressed as the attributable risk for the population as a whole or for a particular category of consanguineous marriages.

To process our data, we also used the chi-two test $x^{2}$ independence realized by the software SPSS: Statistic base, version 22.0.

\section{Result}

Frequency of consanguinity among the population of Beni Abbes

The analysis of the questionnaires completed by the 267 people interviewed revealed a $55.06 \%$ incidence of consanguineous marriages (Table 1). It represents more than half $(1 / 2)$ of the unions among our population.

Table 1 Distribution of consanguinity in the population of Beni Abbes

\begin{tabular}{lll}
\hline Couples & Numbers and percentages \\
\hline Consanguineous couples & 1st cousin & $99(67.35 \%)$ \\
& 2nd cousin & $147(55.06 \%)$ \\
Non-consanguineous couples & $48(32.68 \%)$ \\
& $120(44.94 \%)$ \\
Total couples & $267(100 \%)$ \\
\hline
\end{tabular}

Intergenerational variation of consanguineous marriages among the population of Beni Abbes

In order to verify the evolution in the matrimonial behavior from one generation to the next (grandparents, parents, and children), intergenerational comparisons of inbreeding among the population of Beni Abbes were established based on the data collected from the questionnaires informed by the 267 individuals interviewed in this survey. Table 2 presents the frequency distribution of inbreeding (first-degree consanguine and seconddegree consanguine) over the three generations. A high frequency of $55.06 \%$ was recorded in the generation of couples studied against $53.93 \%$ in the generation of parents and $39.33 \%$ in the generation of grandparents (Table 2).

\section{Inter-local variability in the frequency of consanguineous unions of the population of Beni Abbes compared to those of populations in geographically neighboring regions}

The analysis of the spatial variation of consanguineous marriages in the region of Béchar shows that the consanguinity rates in the populations of Beni ounif, Beni Abbés, and Igli are very high $65.65 \%, 55.06 \%$, and 49.28\%. \% respectively (Fig. 2).

\section{Comparison of the frequency of consanguineous marriages of the population of Beni Abbés to those of the Arab-Muslim world}

The inter-population comparison shows that the population of Beni Abbés has one of the highest frequencies of consanguinity in Arab-Muslim countries. It is lower than that of Kuwait $64.30 \%$ [22] and Jordan $63.7 \%$ [23], is equal to that of Oman $56.3 \%$ [24], is almost double that of Palestine 27.70\% [25], and is three times that of Morocco $19.90 \%$ [26].

\section{Biological effects of consanguineous unions on abortion and mortality}

In order to evaluate the biological effects of consanguineous marriages on the offspring of the inbred population of Beni Abbés, we used direct health

Table 2 Frequency distribution of consanguinity over three generations

\begin{tabular}{lllll}
\hline \multirow{2}{*}{ Generation } & \multicolumn{3}{l}{ Type of wedding } & \\
\cline { 2 - 4 } & \multicolumn{2}{l}{ Consanguineous } & Total & Non-consanguineous \\
\cline { 2 - 3 } & 1st cousin & 2nd cousin & & \\
\hline Couples & $67.35 \%$ & $32.65 \%$ & $55.06 \%$ & $44.94 \%$ \\
Parents & $52.08 \%$ & $47.92 \%$ & $53.93 \%$ & $46.07 \%$ \\
Grandparents & $62.85 \%$ & $37.15 \%$ & $39.33 \%$ & $60.67 \%$ \\
\hline
\end{tabular}




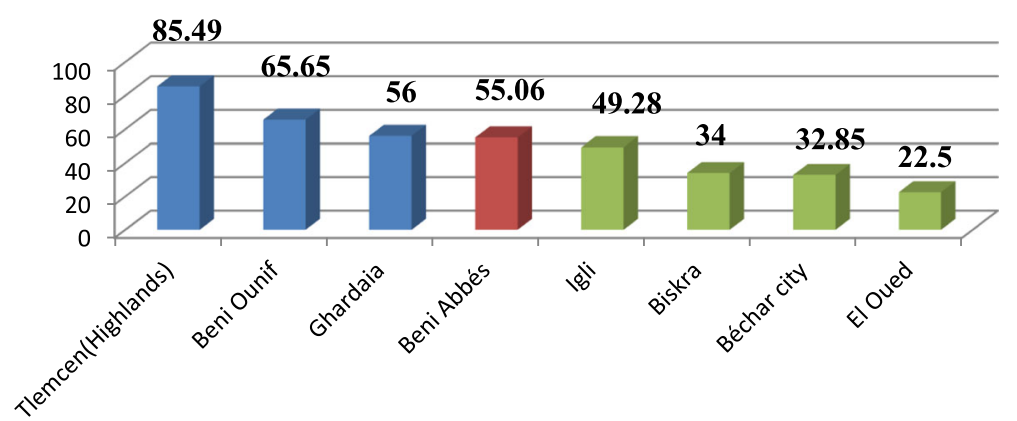

Fig. 2 Frequency of consanguinity in the population of Beni Abbes compared to those of other populations in Algeria. Green indicates rates lower than our value, red indicates our value, and blue indicates rates higher than our value

indicators that are related to obstetrics (fertility of women, abortion, and mortality).

\section{Effects of consanguinity on abortion}

The analysis of the results in Table 3 clearly shows the harmful effect of consanguinity on abortion in Ben Abbes' population. The abortion rate is significantly higher among consanguineous couples compared to non-consanguineous couples, accounting for almost $2 / 3$ of the entire number of registered abortions. First cousin marriages had more cases of abortions than second cousin marriages ones, both for the early and late types. Moreover, the repeatability of abortions (more than one case of abortion in the same couple) was recorded exclusively in consanguineous couples with a clear predominance in the first cousin marriages.

\section{Influence of consanguinity on mortality}

In our population, the relative risk and the attributable risk that takes into account the consanguinity rate are respectively 1.55 and 0.23 . The analysis of the results in Table 4 shows a clear correlation between inbreeding and the mortality rate of the offspring in our population. This correlation is even more significant among first cousin marriages.

\section{Discussion}

Frequency of consanguinity among the population of Beni Abbes

The high level of consanguinity detected (55.06\%) could be explained by the fact that individuals opt for consanguineous marriage as a tradition. The social structure of the Beni Abbes region ensures that families are in many cases very united by socio-economic factors that force members of these families to live in close proximity.

This frequency is significantly higher than the Algerian average of $38.8 \%$ [16]. With regard to the distribution by type of kinship in the population (first cousins marriages and second cousins marriages), a clear preference for 1 st cousin marriages $(37.08 \%)$ is found among the studied couples. This result is in perfect agreement with those recorded in the populations of Tlemcen Mountains and Highlands [15]. However, it does not agree with the results recorded in the populations of Sabra, where there has been a clear preference for 2nd cousin marriages [17].

In his study on consanguineous marriages in Beirut in 1986, Khalt $\mathrm{M}$ indicates that the type of first cousin marriages is most prevalent among ArabMuslim populations and is a characteristic feature of this group [20].

Table 3 Effect of consanguinity on abortions

\begin{tabular}{|c|c|c|c|c|c|c|}
\hline \multirow{2}{*}{$\begin{array}{l}\text { Marriage status } \\
\text { Number of births/178 }\end{array}$} & \multicolumn{4}{|c|}{ Consanguineous } & \multicolumn{2}{|c|}{ Non-consanguineous } \\
\hline & \multicolumn{2}{|l|}{ CC1, 102} & \multicolumn{2}{|l|}{$\mathrm{CC} 2,76$} & \multicolumn{2}{|c|}{149} \\
\hline \multirow[t]{3}{*}{ Number of abortions ( $N$ and \%)/23 (62.16) } & \multicolumn{2}{|c|}{ CC1, $14(37.84)$} & \multicolumn{2}{|c|}{ CC2, 9 (24.32) } & \multicolumn{2}{|l|}{$14(37.84)$} \\
\hline & Early & Late & Early & Late & Early & Late \\
\hline & $5(13.51)$ & $9(24.32)$ & $3(08.11)$ & $6(16.22)$ & $6(16.22)$ & $8(21.62)$ \\
\hline$x^{2}$ & 0.24 & & & & 0.24 & \\
\hline$P$ & 0.00 & & & & 0.23 & \\
\hline
\end{tabular}

Observed value $=3841$

CC1 first-cousin marriage couples, $C C 2$ second-cousin marriage couples, ( $N$ and \%) number and percent 
Table 4 Effect of consanguinity on mortality

\begin{tabular}{llll}
\hline Marriage status & Consanguineous & Non-consanguineous \\
\cline { 2 - 3 } Number of births/178 & CC1, 102 & CC2, 76 & 149 \\
\hline Number of deaths $(N$ and \%)/14(60.87) & $9(39.13)$ & $5(39.13)$ & $9(39.13)$ \\
$X^{2}$ & 0.36 & & 0.36 \\
$P$ & 0.55 & 0.55 \\
\hline
\end{tabular}

Observed value $=3841$

Intergenerational variation of consanguineous marriages among the population of Beni Abbes

These results obtained testify the existence of continuity in the practice of marriages between relatives. The tendency to marry a first cousin is preferable both in the generation of the studied couples $67.35 \%$ than in the parents $52.08 \%$ and in grandparents $62.85 \%$. The high rate of consanguinity across the three generations can be explained by the fact that Beni Abbés has always been a genetic isolate [21] and is likely to continue to be so.

Inter-local variability in the frequency of consanguineous unions of the population of Beni Abbes compared to those of populations in geographically neighboring regions

High consanguinity rates in the three populations of Beni ounif, Beni Abbés, and Igli which respectively $65.65 \%, 55.06 \%$, and $49.28 \%$ can be explained by the fact that these three populations were already genetic isolates according to the 1989 study by Bachir and Abdulkader on the distribution of frequencies of blood groups and their genes on populations in southwestern Algeria [21].

The comparison of the inbreeding rate of the population of Beni Abbés with some populations of geographically neighboring regions (Fig. 2) shows that it is lower than the frequencies recorded in the highlands of the wilaya of Tlemcen [15], relatively close to those recorded in Ghardaiia [16], and it is well below the frequencies recorded in Biskra and El Oued [16].

\section{Comparison of the frequency of consanguineous marriages of the population of Beni Abbés to those of the Arab-Muslim world}

The high consanguinity rate recorded at the end of the study carried out on the population of Beni Abbés (56.06\%) is one of the highest rates in the Arab Muslim world; it reinforces the results obtained by the survey conducted in 2007 in 11 wilayas (from different regions) by the National Foundation for Medical Research (FOREM) that consanguineous marriage is a widespread practice in Algeria and enriched the scientific literature in this field.
Biological effects of consanguineous unions on abortion and mortality

Effects of consanguinity on abortion

The correlation established between consanguinity and abortion in our population is consistent with those in Iraq [27] and Turkey [28], who reported twice as many abortions among first cousin consanguineous couples as in non-consanguineous couples.

On the other hand, our results do not agree with the results of studies realized in Pakistan that has shown lower rates of abortions in families where consanguinity is customary across successive generations, presumably because of the increasing effect homozygosity on fetal development [29].

\section{Influence of consanguinity on mortality}

The values of relative risk (1.55) and attributable risk (0.23) mean that the risk of mortality of children from consanguineous marriages is high compared to that of children from non-consanguineous marriages.

Our results are consistent with those Abbad et al. [13] and Moussouni et al. [17] which unambiguously confirm that prenatal and postnatal mortality rates and infant morbidity increase when couples are in consanguineous unions.

These results reinforce those achieved since 1984 [14], 2007 [16], and 2017 [17], particularly with regard to the negative effects of consanguinity on public health in Algeria, and alert the public authorities to the need to install genetic counseling in services to level of all health structures to reduce these effects.

Despite the results recorded, difficulties in particular social (it was very difficult to convince the subjects to join the survey) which explains the size of the sample compared to the relatively long time to realize the study.

\section{Conclusion}

Through the analysis of consanguinity and two health indicators namely abortion and mortality in the population of Beni Abbes (southwest Algeria), we were able to define the main characteristics explaining its socio-cultural and biological profiles. Thus, consanguineous marriages have been for several generations and continue to be so far, a common social preference in our population and despite the fact that the impact of such unions is 
not very clear. They seem to offer couples and their families, and even society a lot of advantages in terms of the emotional and material security of spouses, more assurance on the stability of marriage, acceptance of parents in their beings and their assets, solidarity, and social cohesion.

The inbreeding rate of $56.06 \%$ revealed by the study conducted on this population remains one of the highest among the Arab-Muslim countries, including the national average of Algeria; nevertheless, it remains below some Arab frequencies and other excessively high frequencies within populations of geographically neighboring regions in Algeria.

These results also reveal the continuity in the practice of consanguineous marriages from one generation to the next, with always a preference of unions between cousins of the first degree.

A harmful impact of consanguinity on abortion and mortality among the population of Beni Abbes was highlighted through this study. This result is in perfect agreement with many studies in this field that confirm a highly significant relationship between consanguinity and some fitness parameters by promoting the expression of deleterious recessive genes under the effect of increasing homozygosity through successive consanguineous generations.

Despite these results, which clearly show, from a genetic point of view, the impact of consanguinity on abortion and mortality, other socio-economic, cultural, and environmental factors, particularly in development, could intervene in the determinism of these two phenomena.

These results are an encouraging indicator for further future genetic studies on this population, especially since this locality is likely to remain a genetic isolate.

In order to reduce the adverse health effects of consanguinity, it is essential to establish genetic counseling services in health facilities and to promote the dissemination of information on risks arising from consanguineous marriages through health education for populations.

\footnotetext{
Abbreviations

AR: Attributable risk; CC: Consanguineous couples; CC1: First-degree consanguineous couples; CC2: Second-degree consanguineous couples; Cousin1: Cousin of first-degree; Cousin2: Cousin of second-degree; FOREM: Foundation for Medical Research; NCC: Non-consanguineous couples; PC: Proportion of Consanguinity; PHEP: Public Health Establishment of Proximity; Rc: Probability of death among children from consanguineous marriages; Rnc: Probability of death among children from nonconsanguineous marriages; RPP: Proportional attributable risk of the population; RR: Relative risk; SPSS: Statistical Package for the Social Sciences; $X^{2}$ : Chi-square test
}

\section{Acknowledgements}

We would like to thank Dr. Métahris Director of PHEP Beni Abbess for his help and assistance in conducting our survey, which greatly facilitated our work.

\section{Authors' contributions}

AA has a substantial contribution to the conception and design of the work and substantively revised manuscript, have approved the submitted version and all modified versions (to comply with the journal standards). BS has contributed to the conception and design of the work, acquisition, analysis, and interpretation of data; have drafted the manuscript; and have finalized the submitted version and all modified versions (to comply with the journal standards). Both authors read and approved the final manuscript.

\section{Funding}

Not applicable

\section{Availability of data and materials}

The data collected during the survey through the questionnaire have been tabulated and are included in the manuscript. However, all the questionnaires containing all the individual information of the subjects interviewed are kept at the level of the laboratory indicated in the manuscript.

\section{Ethics approval and consent to participate}

Everyone included in this study is informed and has given us written consent in accordance with Executive Decree No. 92-276 of 06 July 1992 on the Algerian Code of Medical Ethics.

\section{Consent for publication}

Not applicable

\section{Competing interests}

The authors declare that they have no competing interests.

Received: 30 May 2019 Accepted: 20 June 2019

Published online: 05 August 2019

\section{References}

1. Talbi J, Khadmaoui A, Soulaymani A, Chafik A (2008) Caractérisation de l'évolution de la consanguinité dans la population des Doukkala (Maroc). Antropo 17:7-13

2. Denic S (2003) Consanguinity as risk factor for cervical carcinoma. Med. Hypotheses 60(3):321-324

3. Valls A (1982) Anthropologia de la consanguinidad. Editorial de la Universidad Complutence, Madrid

4. Tadmouri GO, Nair P, Obeid T, Al Ali TM, Al Khaja N, Hamamy HA (2009) Consanguinity and reproductive health among Arabs. Reprod Health 6:17

5. Boutefnouchet M (1980) La famille Algérienne, évolution et caractéristiques récentes. Ed, SNED, Alger

6. Solignac M, Periquet G, Anxolabehere D, Petit C (1995) Génétique et Evolution1: La variation des gènes dans les populations. Collect Meth Herman Ed des Sciences et des Arts:289

7. Zlotogora J, Shalev S, Habiballah H, Barjes S (2000) Genetic disorders among Palestinian arabs: Autosomal recessive disorders in a single village. Am J Med Genet 92:343-345

8. Bittles, A.H. \& Hamamy, H.A. (2010) Endogamy and Consanguineous Marriage in Arab Populations. Dans Genetic Disorders Among Arab Populations, édité par A.S. Teebi (Berlin: Springer-Verlag) p. 85-108.

9. Bener (2012) Consanguineous marriages and their effect on common diseases in the qatari population. Genetic Disord Arab World 4:30-39

10. Yamamah G, Abdel-Raouf E, Talaat A, Saad-Hussein A, Hamamy H, Meguid NA (2013) Prevalence of consanguineous marriages in South Sinai, Egypt. J Biosocial Sci 45:31-39

11. Ehlayel M, Bener A, Abu Laban M (2013) Effects of family history and consanguinity in primar immunodeficiency diseases in children in Qatar. Open J Immunol 3:47-53

12. Saadat M (2015) Association between consanguinity and survival of marriages. Egyptian J Med Hum Genet 16:67-70

13. Abbad Z, Drissi A, Abdelmajid S, Khadmaoui A (2016) Etude de l'impact de la consanguinite sur la sante des descendants dans la population de Tiflet (Maroc). Eur Sci J 12:143-159

14. Benallegue A, Kedji F (1984) Consanguinity and public health. Algerian Study. Arch Fr Pediatr 41:435-440

15. Aouar A, Moussouni A, Mokeddem R, Chalabi FZ (2005) Caractérisation anthropogénétique dans les populations du Littoral, des Monts de Tlemcen, 
des Hauts plateaux par la consanguinité, Mortalité et Morbidité. Travaux de laboratoire de violonce et religions, Tome 3:17-22

16. FOREM: Fondation nationale pour la Recherche Médicale. (2007). EL Watan (le quotidien indépendant). Edition du 19 septembre 2007.

17. Moussouni A, Aouar A, Otmani S, Chabni N, Sidiyekhlef A (2017) Etude de l'impact de la consanguinité sur l'avortement et la mortalité dans la population de Sabra (ouest algérien)

18. Décret exécutif $n^{\circ} 92-276$ du 6 juillet (1992), portant code de déontologie médicale; Journal officiel de la république Algérienne N 52 du 8 juillet 1992.

19. Bouyer, J; Hémon, D ; Cordier, S ; Derriennic, F ; Stücker, I ; Stengel, B. \& Clavel, J. (2009) Epidémiologie : Principes et méthodes quantitatives. Partie I, Mesures de risque et mesures d'association, page 29, Edition Lavoisier 2009.

20. Khlat M (1986) Les mariages consanguins à Beyrouth: Structure et conséquences biologiques. Thèse de doctorat -ès- sciences. Univ, Lyon

21. Bachir, S. \& Abdulkader, N. (Résultats non publiés) Etude de la répartition des fréquences des gènes $A, B, O, D$ et $d$ dans la région de Béchar et Adrar (sud-ouest Algérien), Mémoire des études supérieures (DES) en génétique, Université d'Oran.

22. Radovanovic Z, Shah N, Behbehani J (1999) Prevalence and social correlates to consanguinity in Kuwait. Ann Saudi Med 19:206-210

23. Sueyoshi S, Ohtsuka R (2003) Effects of polygyny and consanguinity on high fertility in the rural Arab population in South Jordan. J Biosoc Sci 35:513-526

24. Rajab A, Patton MA (2000) A study of consanguinity in the Sultanate of Oman. Ann Hum Biol 27:321-326

25. Assaf S, Khawaja M (2009) Consanguinity trends and correlates in the Palestinian Territories. J Biosoc Sci 41:107-124

26. Baali, A. (1994) Etude anthropologique d'une population berbère semiisolée de Haut-Atla (Vallée d'Azgour, cercle d'Amzmiz, Marrakech, Maroc). Thèse d'état, Fac. Sci. Semlalia, Marrakech.

27. Hamamy H, Al-Bayati N, Al-Kubaisy W (1986) Consanguineous marriages in Iraqi urban population and the effect on pregnancy outcome and infant mortality. Iraqi Med J 34:76-80

28. Basaran N, Hassa H, Basaran A, Artan S, Stevenson JD, Sayli BS (1989) The effect of consanguinity on the reproductive wastage in the Turkish population. Clin Genet 36:168-173

29. Hussain R, Bittles AH (1998) The prevalence and demographic characteristics of consanguineous marriages in Pakistan. J Biosoc Sci 30(2):261-275

\section{Publisher's Note}

Springer Nature remains neutral with regard to jurisdictional claims in published maps and institutional affiliations.

\section{Submit your manuscript to a SpringerOpen ${ }^{\circ}$ journal and benefit from:}

- Convenient online submission

- Rigorous peer review

- Open access: articles freely available online

- High visibility within the field

- Retaining the copyright to your article

Submit your next manuscript at $\boldsymbol{\nabla}$ springeropen.com 